Original Article

\title{
Serological prevalence of hepatitis B virus (HBV) in Mardan district, Khyber Pakhtunkhwa, Pakistan
}

\author{
Prevalência sorológica do vírus da hepatite B (HBV) no distrito de Mardan, Khyber \\ Pakhtunkhwa, Paquistão

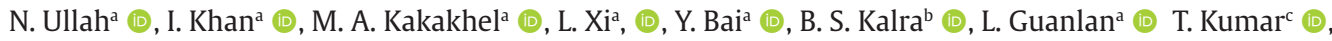 \\ M. Shah ${ }^{\mathrm{d}}$ (D) and C. Zhanga* (D) \\ aLanzhou University, School of Life Sciences, MOE Key Laboratory of Cell Activities and Stress Adaptations, Lanzhou, Gansu, China \\ bVirtual University of Pakistan, Department of Bioinformatics and Computational Biology, Lahore, Pakistan \\ 'State Key Laboratory of grassland Agro-ecosystem, Key Laboratory of Grassland, Livestock Industry Innovation, Ministry of Agriculture, Collage \\ of Pastoral Agriculture Science and Technology, Lanzhou University, Lanzhou, Gansu, China \\ dUniversity of Swat, Centre for Animal Sciences \& Fisheries, Charbagh, Pakistan
}

\begin{abstract}
Hepatitis B virus infection is perilous among the five types of Hepatitis, as it remains clinically asymptomatic. The present study draws up-to-date prevalence of Hepatitis B virus (HBV) in the general population of Mardan, Khyber Pakhtunkhwa Pakistan. The blood samples from 4803 individuals including 2399 male and 2404 females were investigated. All the suspected samples were analyzed for hepatitis B surface antigen using Immuno-chromatographic test (ICT), Enzyme-linked immunosorbent assay (ELISA), and followed by Reverse transcription-polymerase chain reaction (RT-PCR). Results showed that 312 (13.00\%) out of 2399 individuals contained antibodies in their blood against HBV, while among the different age groups, the highest incidences of HBV antibodies were found in the age of 21-30 groups (10.73\%). Furthermore, the ICT positive samples were screened by nested polymerase chain reaction to detect the existence of active HBV-DNA. It was observed that 169 (7.04\%) out of (2399) male of the total population (4803) tested was positive. On the other hand, the female 463 (19.25\%) possessed antibodies in their blood against HBV. Accumulatively, our results showed a higher percentage of HBV prevalence in males than females in the age group 21-30 years. The total HCV infected in Mardan general population was recorded at 5.7\% comprising both male and female.
\end{abstract}

Keywords: HBV prevalence, age groups, anti-HBV antibodies, Mardan, Pakistan.

\begin{abstract}
Resumo
A infecção pelo vírus da hepatite B é perigosa entre os cinco tipos de hepatite, pois permanece clinicamente assintomática. O presente estudo traça a prevalência atualizada do vírus da hepatite B (HBV) na população geral de Mardan, Khyber Pakhtunkhwa, no Paquistão. Amostras de sangue de 4.803 indivíduos, incluindo 2.399 homens e 2.404 mulheres, foram investigadas. Todas as amostras suspeitas foram analisadas para o antígeno de superfície da hepatite B usando teste imunocromatográfico (ICT), enzyme-linked immunosorbent assay (ELISA), seguido por transcrição reversa-reação em cadeia da polimerase (RT-PCR). Os resultados mostraram que $312(13,00 \%)$ de 2.399 indivíduos continham anticorpos no sangue contra o VHB, enquanto, entre as diferentes faixas etárias, as maiores incidências de anticorpos VHB foram encontradas nos grupos de 21 a 30 anos (10,73\%). Além disso, amostras positivas para ICT foram rastreadas por reação em cadeia da polimerase aninhada para detectar a existência de HBV-DNA ativo. Observou-se que 169 (7,04\%) de 2.399 homens do total da população (4803) testados foram positivos. Por outro lado, 463 mulheres (19,25\%) possuíam anticorpos no sangue contra VHB. Acumulativamente, nossos resultados mostraram uma porcentagem maior de prevalência de $\mathrm{HBV}$ em homens do que em mulheres na faixa etária de 21 a 30 anos. $\mathrm{O}$ total de HCV infectados na população geral de Mardan foi registrado em 5,7\%, incluindo homens e mulheres.
\end{abstract}

Palavras-chave: prevalência de VHB, grupos de idade, anticorpos anti-VHB, Mardan, Paquistão.

\section{Introduction}

Hepatitis is the foremost deadly liver infectious disease across the globe. About, 257 million people are living with HBV infection that resulted in 887,000 deaths (WHO, 2015).
Despite that nearly, 350-400 million people are carriers of the surface antigen (HBsAg) of HBV. The highest prevalence of HBV was reported in the Western Pacific

*e-mail: chunjiangz122@sina.com.cn

Received: November 22, 2020 - Accepted: December 4, 2020 
Region 6.2\% and African Region 6.1\% (Hennessey et al., 2013; Schweitzer et al., 2015). There are main five hepatitis viruses comprising A, B, C, D, and E (HAV, HBV, HCV HDV, and HEV) respectively, that severely affect the liver. HBV leads to inhibition of the progression of liver fibrosis, including hepatocellular carcinoma (HCC), normalization of biochemical liver indicators, and leading to liver cirrhosis (Polish Group of Experts for HBV, 2017; Hafeez-ud-din et al., 2012). Hepatitis B was first identified in 1963 and to date, more than 20 million people in Pakistan are suffering from hepatitis B and C resulting in 150,000 new cases each year (Ali et al., 2011).

The high prevalence of HBV in Pakistan causes great suffering to patients and their families those possessing low economic status. It is pivotal to control HBV because $67.5 \%$ of Pakistan's population belongs to rural areas with low socio-economic value (Khan et al., 2011a). Hepatitis B virus shares a similar mode of transmission with HCV. Thus, the major risk factors of HBV are the use of unsterilized tools or instruments, transfusion of unscreened blood and/or blood-related products, shaving by local community barbers using or reused razors, ear and nose piercing, and tattooing with unsterilized needles, sharing toothbrushes of infected person, dental and general surgical operations with unsterilized instruments, poor health work set up in hospitals, dialysis, acupuncture, use of non-sterilized scissors for circumcision, drug abuses and unsafe sex practices (Kumar et al., 2017; Liaw and Chu, 2009; Rantala and van-de-Laar, 2008).

Hepatitis B virus is a major agent for the silent contagious liver infection that may acute or chronic. Nethermost, people remain asymptomatic in the course. However, acute illness along with the common symptoms such as abdomen pain, yellowing of the eyes (Jaundice), and skin extreme fatigue, vomiting or nausea, and dark color of urine. Whereas, acute hepatitis may result in liver failure in a small percentage of the people that might lead to death (Chang, 2007; Rantala and van-de-Laar, 2008). Of significance, the classification of age groups plays a key role in the study of geographical and demographic differences, molecular epidemiology, chronic infection studies, designing therapeutic strategies, and vaccine development (Gul et al., 2016; Kumar et al., 2017). Although, effective vaccines against HBV are available from 1982 (Cassidy et al., 2011). Nevertheless, Adefovir is an effective prescribed medicine to treat HBV infections (Van Bömmel et al., 2004). Entecavir, sold in the market of brand name (Baraclude), for the treatment of HBV infection. Hence, previous studies suggests that Adefovir and Entecavir to be effective against the HBV (Matthews, 2006).

Even though the developing countries like Africa, Asia, and Pacific Island have a high prevalence of HBV in comparison with developed countries like Europe, America, Australia where the prevalence is low. Pakistan is a developing country, having viral hepatitis as a major public health issue (Hasnain, 1994; Schweitzer et al., 2015). There is a need among the large populations of the developing world to study the relationship of HBV by age, gender, route of entry, and the duration of infection (Gul et al., 2016; Kumar et al., 2017). Although documentation of actual HBV infection in Pakistan remains perplexing due to poor management and effective record keeping.

Conversely, PCR based HBV diagnosis provides an extra advantage over non-PCR methods including Enzyme-Linked Immunosorbent Assay (ELISA), Recombinant Immunoblot assay (RIBA), Enzyme Immunoassay for the Qualitative Detection (EIA), Immunochromatography (ICT), and so on, being a quick and reliable tool to diagnose, identification genotype, and quantify HCV and HBV genetic material in the blood. Previously, small studies have been undertaken in different regions of Pakistan (Ahmad et al., 2009; Aslam and Aslam, 2001; Kumar et al., 2017). As the province of Khyber Pakhtunkhwa is highly vulnerable to natural and human-induced disasters, lacks risk reduction measures, and suffers from the overlapping responsibilities from the past many years. Mardan city was decided as one of the suitable sites KP to research due to the increasing population in the last few years, limited resources, and lack of health facilities. To investigate the actual prevalence of HBV in KP province a review of literature from Pakistan published data was also analyzed. The present study will not only help to determine the seroprevalence of $\mathrm{HBV}$ and to compare it with previous investigations but will also attract the attention of local and foreign organizations/researchers towards this serious matter.

\section{Materials and Methods}

\subsection{Population size and sampling}

The Cross-sectional descriptive study was conducted in Mardan city, the second densely populated city of Khyber Pakhtunkhwa, Pakistan by the total population in 2017-2020 counting 358,604. The main language is Pushto locally called (Pakhto). The residents of the area, most of whom came from different parts of the local regions, were taken as a mixed population of Mardan city, Pakistan (Figure 1). All the individuals were assigned in seven different age categories 10-20, 21-30, 31-40, 41-50, 51-60, 61-70, and 71 to above age, respectively. The population was selected based on visiting the concerned small laboratories/collection centers for diagnosis. Subjects consist of comorbidities, and participants younger than 10 years were excluded; those who provide full informed consent were included.

Data for three years from 2017 to 2020 was used with the informed as well as written consent of each patient based on the design questionnaire. The questionnaire included general information and reference to the doctor with history and diagnostic tests. All the confidential information was solemnly used for research purposes. The study was approved by the Ethical Committee and of minor collections laboratories with the collaboration of the School of Life Sciences, Lanzhou University P.R China, and the Virtual University of Pakistan.

\subsection{Identification of $\mathrm{HBV}$ in blood}

From the redial vein of the patients, a $5 \mathrm{ml}$ blood sample was collected in a sterilized gel tube using a disposable syringe. The serum was collected by coagulation of blood 


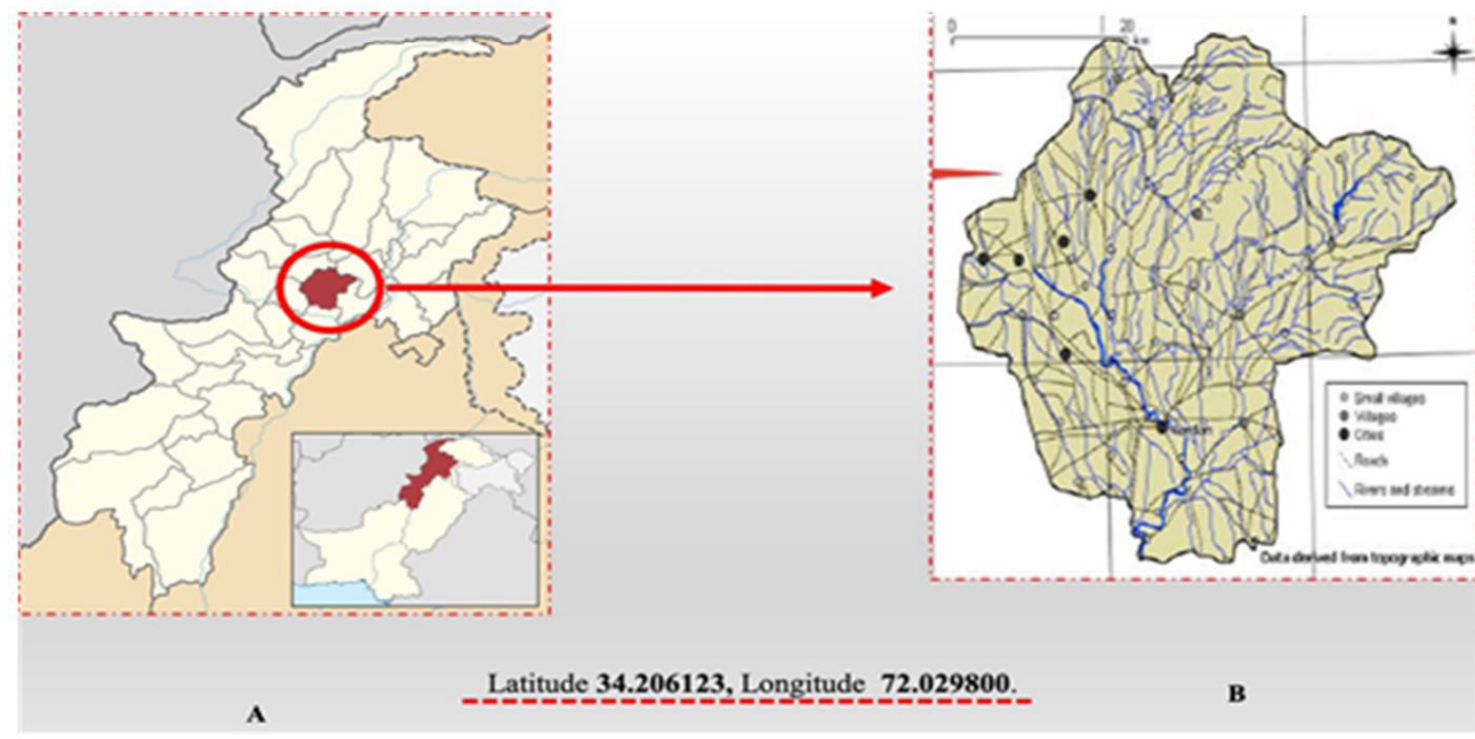

Figure 1. Map of the Khyber Pakhtunkhwa (KP), Pakistan. The district Mardan in encircled, where the present study was conducted for determining the prevalence of active HCV infection and genotypic distribution in the year from 2017-2020.

samples and stored at $-20^{\circ} \mathrm{C}$ until analysis. Initially, all suspected samples of blood were examined by the immuno-chromatographic test (ICT) for HBsAg respectively. The kits and reagents used in this screening were purchased from Abbot (global healthcare and research). Positive samples by ICT were further processed for the next round of examination ELISA and with the help of PCR followed by (Ali et al., 2012).

To investigate HBV positive sera, an ELISA test was conducted for investigation of possible antibodies complementary to its antigen using commercially available kits following the manufacture's protocol (BIO KIT, U.S.A, Barcelona-Spain). The HBsAg positive samples from ELISA were subsequently processed for DNA isolation and nested PCR using commercially available DNA Extraction kits (Sacace, Biotechnology, Italy) using Cepheid smart cycler (Nasdaq: CPHD, California, US). Isolated DNA was dissolved in $50 \mu \mathrm{l}$ of nuclease-free water for nested PCR. In the initial round, the PCR specific primers were used as shown in (Table 1 ). About $20 \mu \mathrm{L}$ of the PCR mixture $(1.5 \mu \mathrm{l}$ of $25 \mathrm{mM} \mathrm{MgCl} 2$ and $1 \mu \mathrm{l}$ of $2.5 \mathrm{mM}$ dNTPs) containing $1 \mu \mathrm{l}$ each of $10 \mu \mathrm{M}$ forward and reverse primers and Taq buffer, $3 \mu$ nuclease-free water were added to $10 \mu l$ of DNA for the first round in PCR machine. The reaction mixture was the same as first for the second round of PCR except for $4 \mu$ l of DNA template and $9.3 \mu$ of nuclease-free water. The thermal cycler conditions were as following; denaturation at $94^{\circ} \mathrm{C}$ for $5 \mathrm{~min}$ and 30 cycles of annealing temperature $52^{\circ} \mathrm{C}$ for $40 \mathrm{sec}, 73^{\circ} \mathrm{C}$ for $30 \mathrm{sec}$, and a final extension of $73^{\circ} \mathrm{C}$ for $5 \mathrm{~min}$. The conditions for the nested PCR were the same as mentioned above. The Prevalence rate was determined as frequency-based with the help of the following Formula 1:

Prevalence $($ as $\%)=100 \times \frac{\text { Number of Positive Samples }}{\text { Number of Total Samples Measured }}$
Table 1. Set of primer run in the nested PCR (i.e. First and second cycle of PCR) the primer pairs.

\begin{tabular}{cc}
\hline $\begin{array}{c}\text { PCR } \\
\text { Cycle } \\
\text { type }\end{array}$ & \multicolumn{1}{c}{ Primers sequence } \\
\hline First & $\begin{array}{l}\text { Forward: 5'-CATCCTGCTGCTATGCCTCATCT-3', } \\
\text { Reverse: 5'-CGAACCACTGAACAAATGGCACT-3 }\end{array}$ \\
& Forward: 5'-GGTATGTTGCCCGTTTGTCCTCT-3' \\
& Reverse: 5'-GGCACTAGTAAACTGAGCCA-3 \\
\hline
\end{tabular}

\section{Results}

\subsection{Gender and age-wise HBV distribution}

In the current study, a total of 4803 samples were collected, of which 2399 were males and 2404 were females. The total observed samples were taken from 10-71 or above years and categorized into seven age groups, initially screened for HBsAg through ICT. All the male HBsAg ICT positive was $10.73 \%$ (2399), further processed by ELISA. ELISA results indicated that out of total tested individuals $312(13.00 \%$ ) were positive for $\mathrm{HBsAg}$ (Table 2). The nested PCR assay of the samples positive by either ELISA or ICT showed that 169 (7.04\%) males with active HBV DNA in their blood (Table 2). Based on age-wise prevalence in males, the results showed that all the age groups were affected. However, the prevalence is not the same across the groups. The highest rate of incidence $10.73 \%$ was found in the age group of 21-30 years, followed by $8.0 \%$ in the age group of $31-40$ while a lower frequency incidence of $1.16 \%$ was observed in the age group of 60-70 years. Likewise, no incidence was seen in the age group of 71 years or above (Table 2).

In the same way, the age-wise prevalence in females was also assessed (Table 3), but lower frequency of HBV 
prevalence than males. In females, all the age groups were found affected differently. In females, the prevalence deviated among the age groups. The highest incidence rate $(7.46 \%)$ was found in the age group $21-30$, followed by $31-40$ age group by $3.93 \%$ while the lowest rate was observed in the age group $60-70$ by $0.66 \%$ (Table 3 ). Interestingly, as compared to male gender a single case was found in females at the age of 71-above year. Among infected individuals, the prevalence of HBV observed a higher incidence in males as compared to females (Table 2 \& 3). The results revealed that $7.04 \%$ (169) of males showed positive HBV-PCR results while the prevalence in females was $4.45 \%$ (107) was achieved (Table 2 and 3).

\subsection{Sex-wise distribution of $\mathrm{HBs} A \mathrm{~g}$}

During the current study, out of 2399 male samples, 312 samples were observed positive for HBs antigen and 169 were reported positive for HBV DNA. In females, 252 samples out of 2404 were reported positive for HBs antigen and HBV DNA. Counting 107 samples were found positive as shown in (Table 4). By calculating total prevalence in the whole selected population harboring HBs antigen showed $11.7 \%$, while for HBV active DNA infection was observed 5.7\%, a typical gel photograph is shown in Figure 2.

\subsection{Sero-prevalence of HBV Online data retrieval}

To compare the important findings, regarding the active HBV for Pakistan were reviewed from PubMed, Google, and World Wide Web (http://webfoundation. org/). All the data were examined manually. From all over the country the average prevalence of HBV in terms of the individual province as well as all four provinces were calculated (Table 5).

\section{Discussion}

Emerging infectious diseases pose a serious threat to public health security; this is especially true in the under developed world because of limited resources to combat.

Table 2. Prevalence of active HBV among the different age groups of males as revealed by ICT, ELISA, and PCR tests.

\begin{tabular}{|c|c|c|c|c|c|c|}
\hline S. No & $\begin{array}{l}\text { Age categories } \\
\text { (years) }\end{array}$ & No. of samples & ICT(+ive) & ELISA(+ive) & $\begin{array}{l}\text { Positive } \\
\text { PCR(+ive) }\end{array}$ & Prevalence (\%) \\
\hline 1 & $10-20$ & 145 & 57 & 25 & 7 & 4.82 \\
\hline 2 & $21-30$ & 773 & 155 & 121 & 83 & 10.73 \\
\hline 3 & $31-40$ & 569 & 118 & 60 & 46 & 8.08 \\
\hline 4 & $41-50$ & 492 & 93 & 53 & 25 & 5.08 \\
\hline 5 & $51-60$ & 222 & 61 & 29 & 6 & 2.70 \\
\hline 6 & $61-70$ & 172 & 41 & 19 & 2 & 1.16 \\
\hline \multirow[t]{2}{*}{7} & 71-or above & 26 & 14 & 5 & 0 & 0 \\
\hline & Total & 2399 & 539 (22.46\%) & $312(13.00 \%)$ & $169(7.04 \%)$ & $32.59 \%$ \\
\hline
\end{tabular}

Table 3. Prevalence of active HBV among the different age groups of females as revealed by ICT, ELISA, and PCR observations.

\begin{tabular}{|c|c|c|c|c|c|c|}
\hline S. No & $\begin{array}{l}\text { Age categories } \\
\text { (years) }\end{array}$ & No. of samples & ICT(+ive) & ELISA(+ive) & $\begin{array}{l}\text { Positive } \\
\text { PCR(+ive) }\end{array}$ & Prevalence (\%) \\
\hline 1 & $10-20$ & 116 & 42 & 26 & 3 & 2.58 \\
\hline 2 & $21-30$ & 831 & 178 & 98 & 62 & 7.46 \\
\hline 3 & $31-40$ & 636 & 102 & 56 & 25 & 3.93 \\
\hline 4 & $41-50$ & 357 & 57 & 31 & 9 & 2.52 \\
\hline 5 & $51-60$ & 263 & 49 & 29 & 6 & 2.28 \\
\hline 6 & $61-70$ & 150 & 19 & 7 & 1 & 0.66 \\
\hline \multirow[t]{2}{*}{7} & 71-or above & 51 & 16 & 5 & 1 & 1.96 \\
\hline & Total & 2404 & $463(19.25 \%)$ & $252(10.48 \%)$ & $107(4.45 \%)$ & $21.40 \%$ \\
\hline
\end{tabular}

Table 4. Sex wise distribution of the anti-HBV antibodies and HBV DNA positive cases.

\begin{tabular}{cccc}
\hline Sex & Total number of samples & Anti-HBV +ve & HBV +ve \\
\hline Male & 2399 & 312 & 169 \\
Female & 2404 & 252 & 107 \\
Total & 4803 & $564(11.7 \%)$ & $276(5.7 \%)$ \\
\hline
\end{tabular}




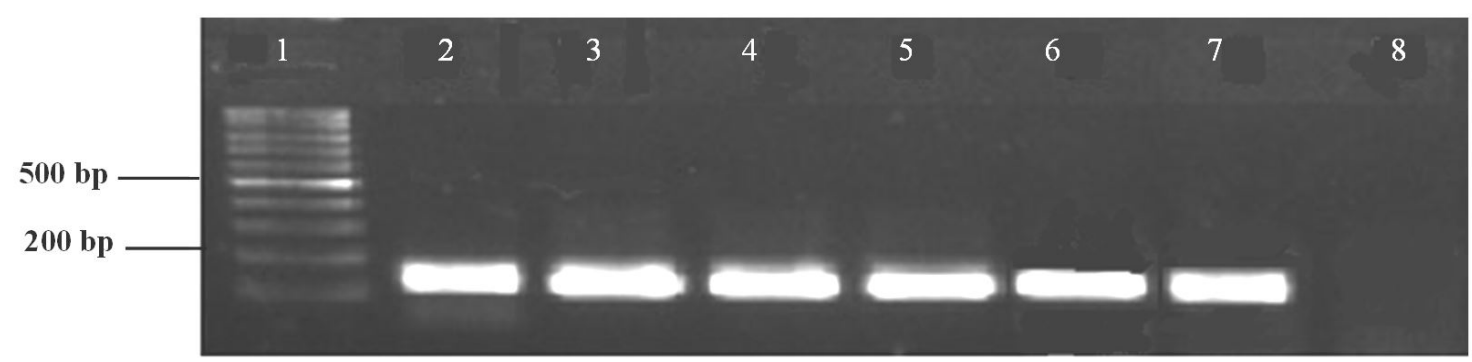

Figure 2. Typical gel photograph of HBV amplified products. Lane 1=1 Kb molecular marker; Lane 2-7 positive samples for active HBV showing 180 bp band of hepatitis B virus; Lane $=8$ negative control.

The emerging pathogens are characterized by a novel mode of pathogenesis and in some cases, a broad host range (Khalil et al., 2017). Hepatitis B infection is an international public health defy that is frighteningly increasing with a prevalence ranging from 2 to $8 \%$ in a different population of Pakistan. This situation is not different from that in the rest of the world (Ahmad, 2016). More specifically, in acute hepatitis patients harbor the serum of HBsAg are likely to be carriers or have a severe risk factor for causing chronic liver disease, in developing countries like India, Bangladesh, and Pakistan. (Sheikh et al., 2011). Mardan is in the southwest of province KP, Pakistan (Figure 1). The proportion of the urban district is $20.2 \%$ whereas $79.8 \%$ is the rural proportion. A report conducted by the Government of Pakistan has mentioned that compared to urban areas hepatitis prevalence is more in rural areas. The disease outbreaks are complex and often not well understood. The experimental design of the current study aims to inquire about the prevalence of $\mathrm{HBV}$ in the Mardan KPK, Pakistan, being the second central city to the northern part of Pakistan. These findings signifying that most HBV positive subjects belong to the rural areas of low economic eminence (Akbar et al., 1997). The Mardan city was undertaken because its entire districts have a comparatively higher mixed population. These districts are facing basic health prerequisites problems. Previous findings were more concerned about antibodies-based tests and non-PCR methods including ELISA, RIBA (Table 5). In our recent findings, molecular-based techniques (RT-PCR) combined with ICT and ELISA was used to draw the exact picture of active HBV prevalence and infection in between the different age groups comprising males and females. The data support the hypothesis of a homogeneous distribution of HBV infection between the male and female due to various outdoor factors (Ahmad et al., 2017; Akbar et al., 1997).

The patients treated for hepatitis $B$ and $C$ in the past 2 years through Prime Minister Program for the Prevention and Control of Hepatitis Viral Infection were screened from 12 different regions. A success rate of $67 \%$ was stated for PCR reports of 1686 patients, which were available and about 33\% were non-responders. An estimated 3440 (45.4\%) patients among 7572 patients completed 6 months of interferon therapy (Qureshi et al., 2013). To mitigate the risks associated with HBV, there is an urgent need to understand the interactions of pathogen host interaction, to monitor molecular evolution and genomic surveillance.
The present study confirms a 5.7\% prevalence (Table 4) of HBV throughout Mardan city compared with other parts of Pakistan (Table 5). Prevalence frequency distribution of hepatitis B infection was reported lower in females $(4.45 \%)$ in comparison with males where it is (7.04\%). Our results suggest that the male community is acquiring HBV infection more quickly and maximizing prone to exposure of outer environment in contrast to females who spend mostly household life.

Barber shaving, homosexuality heterosexuality and use of drugs are very customary in these areas which are in line for the arguments for such higher occurrence of HBV among males. Similarly, HBV higher incidence in males followed by females was observed when risk factors regarding hepatitis $B$ and $C$ infection were observed in the liver, stomach in Karachi and Peshawar (Khan et al., 2011b; Kumar et al., 2017, 2020; Shazi and Abbas, 2006). Earlier studies also confirmed a high prevalence of HBV cases in males as compared to females in Pakistan (Alam et al., 2007; Mahtab et al., 2008) Similarly, the prevalence of HBV infection is higher in Bangladesh in males to females almost $67.86 \%$ to $32.14 \%$ (Khan and Ahmad, 2014). The increase in the prevalence of HBV in males reflects high-risk factors in Asian males. These risk factors include a high use of drugs, sharing of barber shaving razors and multiple sex partners as compared to women.

In Pakistan, a Disease Early Warning System (DEWS) was shaped in 2005 through the collaboration of WHO and the Federal Ministry of Health (FMH) with the goal of early detection of infectious pathogens to overcome morbidity and mortality. Unfortunately, it was not implemented at the grassroots level (Tanveer and Shinwari, 2015). A survey report in Pakistan about the awareness among professional scientists raises alarms about biosafety and biosecurity (Janjua and Nizamy, 2004). Espacially Balochistan and Faisalabad which have high frequency of hepatitis B and C (Ahmad et al., 2007a, b) In this investigation, almost all age groups were found to be affected by HBV. However, a higher prevalence exists at young ages of either males or females. The higher prevalence among younger age groups may be endorsed to the more frequent acquaintance to risk factors and persistent HBV infection.

The barber risk factor is one of the major causes and the route of transmission for HBV infections in Pakistan. At a young age, peoples are not aware much and even do not care/complete the therapy. Second, due to low socioeconomic eminence some child work or young age 


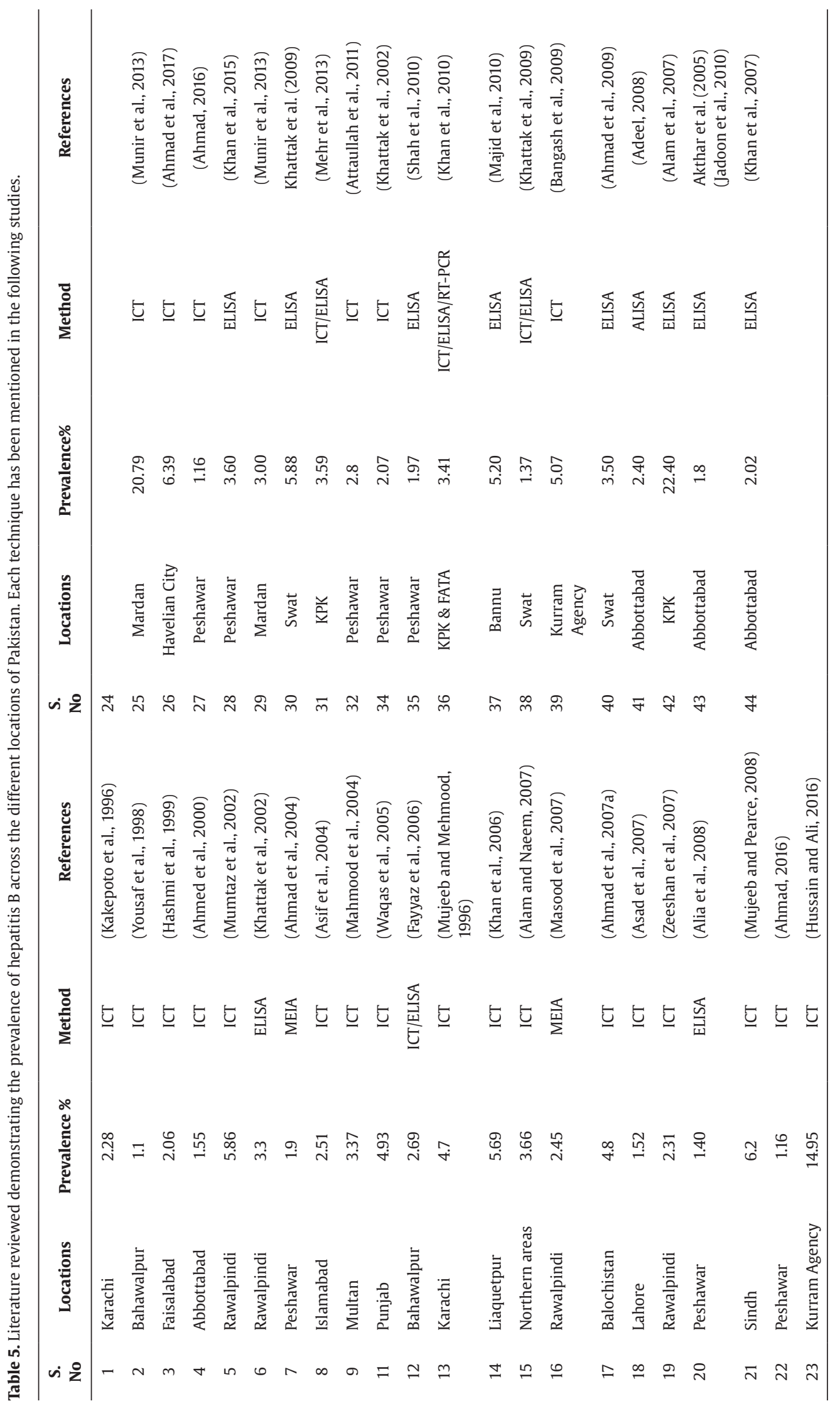


labor collecting raw or waste materials specially used injection, etc. from public spot and streets that may increase the rate of infection. The frequency of exposure to $\mathrm{HBV}$ is higher in male gender $(32 \%)$ who routinely shaved with community barbers. Previous studies showed in Pakistan nearly $46 \%$ of the barbers reuse the blades, ultimately resulting in the increased transmission of HBV infection in the community blades (Kumar et al., 2020; Mahtab et al., 2008). Other risk factors in this area might be associated with contaminated dental surgery, large numbers of refugees an underdeveloped region that is at war, and internally displaced people (IDPs) for the reason of ongoing war against militants and terror represent another major obstacle to the health care system (Attaullah et al., 2011; Rauf et al., 2011). Under-funded and ill-equipped healthcare facilities due to the ongoing war and infrastructure collapse of terrorist activities represent the biggest obstacles to health care of Pakistan. The lack of emergency medical services in Pakistan and initial help to victims are commonly provided by the untrained worker but well-meaning people at the scene is another major cause of an abrupt increase in hepatitis. In the province of KP, populations has an approximately high prevalence rate $3.0 \%$ of more than 30.52 million; KP has more than 10 million HBV carriers and contributes a large proportion to the worldwide pool of HBV carriers (Bukhari et al., 1999).

In our practical observations, most of the patients are associated with low economic status and visited by local medical practitioners for medical checkups. No proper sterilization methods and contaminated equipment reuse might be a possible reason for the high rate of prevalence in this area. Sharing personal materials like shaving razors, nail cutters, the needle used for ear and nose piercing, toothbrushes, and close personal or sexual contact with an infected person has also been reported contributing as major risk factors for hepatitis $B$ virus infection in the young age (Janjua and Nizamy, 2004; Kumar et al., 2020, 2017). The dilemma is not only restricted to natural outbreaks but also bioterrorism attacks using engineered viruses by non-state agents cannot be ignored in the region. At present, Pakistan may not have the capacity to deal with these issues itself so far. High head to toe efforts is required by the international community to reduce the existing threat of hepatitis diseases by educating communities, providing funds to facilitate healthcare personnel, and by providing better treatment facilities to reduce the mortality rate. A risk factor study related to HBV infection in Pakistan would give important evidence to the health planners and the disease control department to overcome the spread of disease. Proper preventive measures, public awareness, and vaccination programs should be launch sooner or later. The government and health authorities need to re-enforce the management and control strategies.

\section{Conclusion}

The current studies highlighted the seroprevalence of HBV in between the various age groups. HBV is an avertible disease and can be treated by immunization or vaccination. In the present portfolio, males are more exposed to high prevalence in comparison with females. Although the infection was more proliferated between the younger groups either male or female. Besides, Mardan is still dominant in HBV infection, there is a pressing need for major awareness events should be launched by KP Government or local authorities and (NGOs) non-government organizations, ample to adopt preventive measures to control the outspread of such dreadful disease.

\section{Acknowledgements}

The authors express their sincere gratitude to the local Medical Centers and Hospitals of Mardan, KP, Pakistan, for granting this award for their research. Also extend esteemed thanks to all the concerned friends, doctors' medical clinicians, and patients for their cooperation as well as their support throughout this study. The authors are also very grateful for the Chinese Government Scholarship Council for the award of Doctoral studies at Lanzhou University.

\section{References}

ADEEL, M.Y., 2008. Seroprevalence of hepatitis B and hepatitis C in health care workers in Abbottabad. Journal of Ayub Medical College, Abbottabad, vol. 20, no. 3, pp. 27-29. PMid:19610509.

AHMAD, A., AHMAD, B., ALI, A. and AHMAD, Y., 2009. Seroprevalence of HBsAg and anti-HCV in general healthy population of Swat district with frequency of different HCV Genotypes. Pakistan Journal of Medical Sciences, vol. 25, pp. 744-748.

AHMAD, F., REHMAN, M.U., JADOON, M.A., HAYAT, A., KHAN, I. and ULLAH, R., 2017. Prevalence of hepatitis B and $C$ infection in Havelian City, Khyber: Pakhtunkhwa, Pakistan. Journal of Entomology and Zoology Studies, vol. 5, pp. 1024-1026.

AHMAD, I., 2016. Prevalence of hepatitis B and C viral infection among pregnant women in Peshawar, Pakistan. Hepatitis Monthly, vol. 16, no. 6, pp. e36383. http://dx.doi.org/10.5812/ hepatmon.36383. PMid:27630725.

AHMAD, J., TAJ, A.S., RAHIM, A., SHAH, A. and REHMAN, M., 2004. Frequency of Hepatitis $B$ and Hepatitis $C$ in healthy blood donors of NWFP: a single center experience. Journal of Postgraduate Medical Institute, vol. 18, no. 3, pp. 343-352.

AHMAD, K. Z., ASLAM, M.I. and ALI, S., 2007a. The frequency of hepatitis B and $\mathrm{C}$ among volunteer blood donors in Balochistan. Hepatitis Monthly, vol. 7, no. 2, pp. 73-76.

AHMAD, N., ASGHER, M., SHAFIQUE, M. and QURESHI, J.A., 2007b. An evidence of high prevalence of Hepatitis $C$ virus in Faisalabad, Pakistan. Saudi Medical Journal, vol. 28, no. 3, pp. 390-395. PMid:17334466.

AHMED, F., SHAH, S.H., TARIQ M. and KHAN, J.A., 2000. Prevalence of hepatitis B carrier and HIV in healthy blood donors at Ayub Teaching Hospital. Pakistan Journal of Medical Research, vol. 39, pp. 91-92.

AKBAR, N., BASUKI, B., MULYANTO., GARABRANT, D.H., SULAIMAN, A. and NOER, H.M..1997. Ethnicity, socioeconomic status, transfusions and risk of hepatitis $B$ and hepatitis $C$ infection. Journal of Gastroenterology and Hepatology, vol. 12, no. 11, pp. 752-757. http://dx.doi.org/10.1111/j.1440-1746.1997.tb00365.x. PMid:9430042.

AKHTAR, S., YOUNUS, M., ADIL, S., HASSAN, F. and JAFRI, S.H., 2005. Epidemiologic study of chronic hepatitis B virus 
infection in malevolunteer blood donors in Karachi, Pakistan. BMC Gastroenterology, vol. 5, no. 1, pp. 26. http://dx.doi. org/10.1186/1471-230X-5-26.

ALAM, M. and NAEEM, M.A., 2007. Frequency of hepatitis B surface antigen and anti-hepatitis $C$ antibodies in apparently healthy blood donoars in northern areas. Pakistan Journal of Pathology, vol. 18, pp. 11-14.

ALAM, M.M., ZAIDI, S.Z., SHAUKAT, S., SHARIF, S., ANGEZ, M., NAEEM, A., SALEHA, S., BUTT, J.A. and MALIK, S.A., 2007. Common Genotypes of Hepatitis B virus prevalent in Injecting drug abusers (addicts) of North West Frontier Province of Pakistan. Virology Journal, vol. 4, no. 63, pp. 1-6. http://dx.doi. org/10.1186/1743-422X-4-63. PMid:17597548.

ALI, A., NISAR, M., IDREES, M., AHMAD, H., HUSSAIN, A., RAFIQUE, S., SABRI, S., REHMAN, H., ALI, L., WAZIR, S. and KHAN, T., 2012. Prevalence of HBV infection in suspected population of conflictaffected area of war against terrorism in North Waziristan FATA Pakistan. Infection, Genetics and Evolution, vol. 12, no. 8 , pp. 1865-1869. https://doi.org/10.1016/j.meegid.2012.07.008.

ALI, M., IDREES, M., ALI, L., HUSSAIN, A., UR REHMAN, I., SALEEM, S., AFZAL, S. and BUTT, S., 2011. Hepatitis B virus in Pakistan: a systematic review of prevalence, risk factors, awareness status and genotypes. Virology Journal, vol. 8, no. 1, pp. 102. http://dx.doi.org/10.1186/1743-422X-8-102. PMid:21375760.

ALIA, Z., WAHEED, Z.T., KASHAN, A., LIAQAT, A., FARAH, F. and SAEED, R., 2008. Seroprevalence of Hepatitis B, C and HIV in healthy blood donors in Northern Pakistan. Pakistan Journal of Pathology, vol. 19, pp. 101-106.

ASAD, U.I., FUAD, S., NAVEED, A., MAHMOOD, N.M. and RIAZ, Q., 2007. Hepatitis B and Hepatitis $C$ in blood donors. Annals of King Edward Medical College, vol. 13, pp. 59-61.

ASIF, N., KHOKHAR, N. and ILAHI, F., 2004. Sero-prevalence of HBV, $\mathrm{HCV}$, and HIV infection among voluntary non remunerated \& replacement donors in Northern Pakistan. Pakistan Journal of Medical Sciences, vol. 20, pp. 24-28.

ASLAM, M. and ASLAM, J., 2001. Seroprevalence of the antibody to hepatitis $C$ in select groups in the Punjab region of Pakistan. Journal of Clinical Gastroenterology, vol. 33, no. 5, pp. 407411. http://dx.doi.org/10.1097/00004836-200111000-00013. PMid:11606859.

ATTAULLAH, S., KHAN, S., NASEEMULLAH., AYAZ, S., KHAN, S.N., ALI, I., HOTI, N. and SIRAJ, S., 2011. Prevalence of HBV and HBV vaccination coverage in health care workers of tertiary hospitals of Peshawar, Pakistan. Virology Journal, vol. 8, no. 1, pp. 1-5. http://dx.doi.org/10.1186/1743-422X-8-275. PMid:21645287.

BANGASH, M.H., BANGASH, T.H. and ALAM, S., 2009. Prevalance of hepatitis $B$ and hepatatis $C$ among healthy blood donors at Kurram agency. Journal of Postgraduate Medical Institute, vol. 23, no. 2, pp. 140-145.

BUKHARI, S.M., KHATOON, N., IQBAL, A., NAEEM, S., SHAFQAT, S., LONE, A. and NAVEED, I.A., 1999. Prevalence of hepatitis B antigenaemia in Mayo Hospital Lahore. Biomedica, vol. 15, pp. 88-91.

CASSIDY, A., MOSSMAN, S., OLIVIERI, A., RIDDER, M.D. and LEROUXROELS, G., 2011. Hepatitis B vaccine effectiveness in the face of global HBV genotype diversity. Expert Review of Vaccines, vol. 10, no. 12, pp. 1709-1715. http://dx.doi.org/10.1586/erv.11.151. PMid:22085174.

CHANG, M.-H., 2007. Hepatitis B virus infection. Seminars in Fetal E Neonatal Medicine, vol. 12, no. 3, pp. 160-167. http://dx.doi. org/10.1016/j.siny.2007.01.013. PMid:17336170.
FAYYAZ, M., KHAN, M.A., QAZI, M.A.L.I., DINCHAUDHARY, G.M., and AHMED, G., 2006. Hepatitis B, C \& HIV. The Professional Medical Journal, vol. 13, pp. 632-636.

GUL, A., AHMED, J., ZAHIR, F., ALI KHAN, I. and ALI, I., 2016. New patterns of HCV subtypes distribution in the Khyber Pakhtunkhwa province of Pakistan. The Brazilian Journal of Infectious Diseases, vol. 20, no. 1, pp. 107-108. http://dx.doi. org/10.1016/j.bjid.2015.09.007. PMid:26626168.

HAFEEZ-UD-DIN., SIDDIQUI, T.S., LAHRASAB, W. and SHARIF, M.A., 2012. Prevalence of hepatitis $B$ and $C$ in healthy adult males of paramilitary personnel in Punjab. Journal of Ayub Medical College, Abbottabad, vol. 24, no. 3-4, pp. 138-140. PMid:24669635.

HASHMI, Z.Y., CHAUDRY, A.H., AHMED, M. and ASHRAF, M., 1999. Hepatitis B virus antigenemia in healthy blood donors in Faisalabad. Prof., vol. 6, pp. 547-550.

HASNAIN, S.S., 1994. Hepatitis prevention, vaccination, treatment. Medical Heritage, vol. 1, pp. 15-19.

HENNESSEY, K., MENDOZA-ALDANA, J., BAYUTAS, B., LORENZOMARIANO, K.M. and DIORDITSA, S., 2013. Hepatitis B control in the World Health Organization's Western Pacific Region: targets, strategies, status. Vaccine, vol. 31, suppl. 9, pp. J85-J92. http://dx.doi.org/10.1016/j.vaccine.2012.10.082. PMid:24331026.

HUSSAIN, S. and ALI, Z., 2016. Prevalence of hepatitis B virus in the Kurram Agency, Pakistan: A 5-year observational study in a war-affected region. Journal of Clinical Virology, vol. 82, pp. 17-19. http://dx.doi.org/10.1016/j.jcv.2016.06.009. PMid:27393939.

JADOON, A.N., SHAHZAD, A.M., YAQOOB, R., HUSSAIN, M. and NASEEMA, A., 2010. Seroprevalence of hepatitis $C$ in type 2 diabetes: evidence for a positive association. Virology Journal, vol. 7, no. 1, pp. 304. http://dx.doi.org/10.1186/1743-422X-7-304.

JANJUA, N.Z. and NIZAMY, M.A.M., 2004. Knowledge and practices of barbers about hepatitis $B$ and $C$ transmission in Rawalpindi and Islamabad.JPMA. The Journal of the Pakistan Medical Association, vol. 54, no. 3, pp. 116-119. PMid:15129868.

KAKEPOTO, G.N., BHALLY, H.S., KHALIQ, G., KAYANI, N., BURNEY, I.A., SIDDIQUI, T. and KHURSHID, M., 1996. Epidemiology of blood-borne viruses: a study of healthy blood donors in Southern Pakistan. The Southeast Asian Journal of Tropical Medicine and Public Health, vol. 27, no. 4, pp. 703-706. PMid:9253870.

KHALIL, A.T., ALI, M., TANVEER, F., OVAIS, M., IDREES, M., SHINWARI, Z.K. and HOLLENBECK, J.E., 2017. Emerging viral infections in Pakistan: issues, concerns, and future prospects. Health Security, vol. 15, no. 3, pp. 268-281. http://dx.doi.org/10.1089/ hs.2016.0072. PMid:28636447.

KHAN, F., AKBAR, H., IDREES, M., KHAN, H., SHAHZAD, K. and KAYANI, M.A., 2011a. The prevalence of HBV infection in the cohort of IDPs of war against terrorism in Malakand Division of Northern Pakistan. BMC Infectious Diseases, vol. 11, pp. 176. http://dx.doi.org/10.1186/1471-2334-11-176. PMid:21689435.

KHAN, H., and AHMAD, I., 2014. Internally displaced persons and health challenges. Gomal Journal of Medical Sciences, vol. 12, no. 2, pp. 43-44.

KHAN, M., HUSSAIN, F. and MUSHARAF, S., 2011b. A fraction of fresh water algae of Kalpani stream and adjoining area of district Mardan, Pakistan. International Journal of Biosciences, vol. 1, pp. 2220-6655.

KHAN, M.A., ASHRAF, M., REHMAN, A., ALI, A., ASHRAF, M. and DITTA, A., 2006. Prevalence of HBV, HCV and HIV in blood donors at Liaquetpur. The Professional Medical Journal, vol. 13, pp. 23-26.

KHAN, M.S., JAMIL, M., JAN, S., ZARDAD, S., SULTAN, S. and SAHIBZADA, A.S., 2007. Prevalence of hepatitis 'B' and 'C'in 
orthopaedics patients at Ayub Teaching Hospital Abbottabad. Journal of Ayub Medical College, Abbottabad, vol. 19, no. 4, pp. 82-84. PMid: 18693606.

KHAN, N.U., SIDDIQUE, L., ALI, I., IQBAL, A., MUNIR, I., RASHID, F., ALI, S., RAZIQ F. and SWATI, Z.A., 2010. Prevalence of hepatitis $B$ in the blood donors of NW. FP and FATA regions and the current scenario of HBV infection in Pakistan. African Journal of Biotechnology, vol. 9, pp. 6162-6166.

KHAN, Z.A., SHAFIQ M., and SHAHAB, F., 2015. Frequency and risk factors of hepatitis $b$ \& $c$ in afghan patients Presenting to tertiary care hospital in Peshawar. Pakistan Armed Forces Medical Journal, vol. 65, no. 5, pp. 686-689.

KHATTAK, M.F., SALAMAT, N., BHATTI, F.A. and QURESHI, T.Z., 2002. Seroprevalence of hepatitis B, C and HIV in blood donors in northern Pakistan. JPMA. The Journal of the Pakistan Medical Association, vol. 52, no. 9, pp. 398-402. PMid:12532573.

KHATTAK, S.T., ALI MARWAT, M., KHATTAK, I., KHAN, T.M. and NAHEED, T., 2009. Comparison of frequency of hepatitis B and hepatitis $C$ in pregnant women in urban and rural area of district Swat. Journal of Ayub Medical College, Abbottabad, vol. 21, no. 2, pp. 12-15. PMid:20524459.

KUMAR, T., AHMAD, N., HAYAT, M.K., GAO, B.-X., FAISAL, S., ILAHI, N., ALI, B., ZADA, S. and SAJJAD, W., 2017. Prevalence and genotypic distribution of hepatitis $C$ virus in Peshawar KPK, Pakistan. Hayati Journal of Biosciences, vol. 24, no. 1, pp. 22-25. http://dx.doi.org/10.1016/j.hjb.2017.04.002.

KUMAR, T., ZADA, S., IRFAN, M., BATOOL, H. and SAJJAD, W., 2020. Serological prevalence of Hepatitis B Virus in Peshawar, Khyber Pakhtunkhwa, Pakistan. Pakistan Journal of Zoology, vol. 52, no. 2, pp. 525. http://dx.doi.org/10.17582/journal.pjz/20190213140254.

LIAW, Y.-F. and CHU, C.-M., 2009. Hepatitis B virus infection. Lancet, vol. 373, no. 9663, pp. 582-592. http://dx.doi.org/10.1016/ S0140-6736(09)60207-5. PMid:19217993.

MAHMOOD, M.A., KHAWAR, S., ANJUM, A.H., AHMED, S.M., RAFIQ S., NAZIR, I., and USMAN, M., 2004. Prevalence of hepatitis B, $\mathrm{C}$ and HIV infection in blood donors of Multan region. Annals of King Edward Medical University, vol. 10, no. 4. https://doi. org/10.21649/akemu.v10i4.1264.

MAHTAB, M.-A., RAHMAN, S., KARIM, M.F., KHAN, M., FOSTER, G., SOLAIMAN, S. and AFROZ, S., 2008. Epidemiology of hepatitis $\mathrm{B}$ virus in Bangladeshi general population. Hepatobiliary $\mathcal{E}$ Pancreatic Diseases International, vol. 7, no. 6, pp. 595-600. PMid:19073404.

MAJID, A., KHAN, M.S. and ULLAH, S., 2010. Rising prevalence of hepatitis $B$ and $C$ and risk factors at district headquarter teaching hospital Bannu, Khyber Pakhtunkhwa. Journal of the College of Physicians and Surgeons--Pakistan, vol. 20, no. 7, pp. 492-493. PMid:20642957.

MASOOD, R., SARDAR, M.A. and MALLHI, A.A., 2007. Seroprevalence of hepatitis $B$ and $C$ among the healthy blood donors at Fauji Foundation Hospital, Rawalpindi. Pakistan Journal of Medical Sciences, vol. 23, pp. 64-67.

MATTHEWS, S.J., 2006. Entecavir for the treatment of chronic hepatitis B virus infection. Clinical Therapeutics, vol. 28, no. 2, pp. 184-203. http://dx.doi.org/10.1016/j.clinthera.2006.02.012. PMid:16678641.

MEHR, M.T., KHAN, H., NISA, Q.U., and IMAN, N.U., 2013. Frequency of hepatitis B \& C infection in newly recruited civil servants in Khyber Pakhtunkhwa. Khyber Medical University Journal, vol. 5, no. 2, pp. 95-97.

MUJEEB, S.A. and MEHMOOD, K., 1996. Prevalence of HBV, HCV and HIV infections among family blood donors. Annals of
Saudi Medicine, vol. 16, no. 6, pp. 702-703. http://dx.doi. org/10.5144/0256-4947.1996.702. PMid:17429278.

MUJEEB, S.A. and PEARCE, M.S., 2008. Temporal trends in hepatitis $B$ and $C$ infection in family blood donors from interior Sindh, Pakistan. BMC Infectious Diseases, vol. 8, no. 1, pp. 43. http:// dx.doi.org/10.1186/1471-2334-8-43. PMid:18402660.

MUMTAZ, S., REHMAN, M.U., MUZAFFAR, M., HASSAN, M.U. and IQBAL, W., 2002. Frequency of seropositive blood donors for hepatitis B, C and HIV viruses in railway hospital Rawalpindi. Pakistan Journal of Medical Research, vol. 41, pp. 51-53.

MUNIR, M., SHAMS, S., LODHI, M.A., PARVEEN, Z. and ULLAH, N., 2013. Prevalence of Hepatitis B in the Students, and Employees of Abdul Wali Khan University Mardan Shankar Campus. Pakhtunkhwa Journal of Life Science, vol. 3, pp. 120-129.

POLISH GROUP OF EXPERTS FOR HBV, FLISIAK, R., HALOTA, W., JAROSZEWICZ, J., JUSZCZYK, J., MAŁKOWSKI, P., PAWŁOWSKA, M., PIEKARSKA, A., SIMON, K., TOMASIEWICZ, K. and WAWRZYNOWICZ-SYCZEWSKA, M., 2017. Recommendations for the treatment of hepatitis B in 2017. Clinical and Experimental Hepatology, vol. 3, no. 2, pp. 35-46. http://dx.doi.org/10.5114/ ceh.2017.67626. PMid:28856289.

QURESHI, H., MOHAMUD, B.K., ALAM, S.E., ARIF, A. and AHMED, W., 2013. Treatment of hepatitis $B$ and $C$ through national programme: an audit.JPMA. The Journal of the Pakistan Medical Association, vol. 63, no. 2, pp. 220-224. PMid:23894899.

RANTALA, M. and VAN DE LAAR, M.J., 2008. Surveillance and epidemiology of hepatitis $B$ and $C$ in Europe-a review. Eurosurveillance, vol. 13, no. 21, pp. 18880. http://dx.doi. org/10.2807/ese.13.21.18880-en. PMid:18761967.

RAUF, A., NADEEM, M.S., ALI, A., IQBAL, M., MUSTAFA, M., LATIF, M.M., LATIF, M.Z., AHMED, N. and SHAKOORI, A.R., 2011. Prevalence of hepatitis $B$ and $C$ in internally displaced persons of war against terrorism in Swat, Pakistan. European Journal of Public Health, vol. 21, no. 5, pp. 638-642. http://dx.doi.org/10.1093/ eurpub/ckq084. PMid:20601693.

SCHWEITZER, A., HORN, J., MIKOLAJCZYK, R.T., KRAUSE, G. and OTT, J.J., 2015. Estimations of worldwide prevalence of chronic hepatitis B virus infection: a systematic review of data published between 1965 and 2013. Lancet, vol. 386, no. 10003, pp. 15461555. http://dx.doi.org/10.1016/S0140-6736(15)61412-X. PMid:26231459.

SHAH, S.M.A., KHATTAK, I., ALI, A. and TARIQ M., 2010. Seropositivity for hepatitis B and C in voluntary blood donors. Journal of Ayub Medical College, Abbottabad, vol. 22, no. 3, pp. 149-151. PMid:22338442.

SHAZI, L. and ABBAS, Z., 2006. Comparison of risk factors for hepatitis $B$ and $C$ in patients visiting a gastroenterology clinic. Journal of the College of Physicians and Surgeons--Pakistan : JCPSP, vol. 16, no. 2, pp. 104-107. PMid:16499801.

SHEIKH, N. S., SHEIKH, A. S., SHEIKH, A. A., YAHYA, S., RAFI-USHAN and LATEEF, M., 2011. Sero-prevalence of hepatitis B virus infection in Balochistan Province of Pakistan. Saudi journal of gastroenterology : official journal of the Saudi Gastroenterology Association, vol. 17, no. 3, pp. 180-184. http:// dx.doi.org/10.4103/1319-3767.80380. PMid:21546720.

TANVEER, F., and SHINWARI, Z.K., 2015. Survey on general awareness about bio-security and dual-use related concepts among educators of graduate life sciences in Pakistan. Dual Use Education Concerns in Biotechnology; A Pakistan Perpsective. Islamabad: Pakistan Academy of Sciences, pp. 38-49.

VAN BÖMMEL, F., WÜNSCHE, T., MAUSS, S., REINKE, P., BERGK, A., SCHÜRMANN, D., WIEDENMANN, B. and BERG, T., 2004. Comparison of adefovir and tenofovir in the treatment of lamivudine-resistant hepatitis B virus infection. Hepatology 
(Baltimore, Md.), vol. 40, no. 6, pp. 1421-1425. http://dx.doi. org/10.1002/hep.20464. PMid:15565615.

WAQAS, J., FAROOQ A., USMAN, S., TEHSEEN, I. and HAMID, J.Q., 2005. Prevalence of Hepatitis B, C and HIV in blood donors of South Punjab. Sims J, vol. 100, pp. 13-16.

WORLD HEALTH ORGANIZATION - WHO, 2015. Guidelines for the prevention care and treatment of persons with chronic hepatitis B infection. Geneva: WHO.
YOUSAF, M., HASAN, S.M.A. and KAZMI, S.H., 1998. Hepatitis B, Carriers Prevalence of HBs Ag among volunteer blood donors in Bahawalpur division. The Professional Medical Journal, vol. 5, pp. 267-271.

ZEESHAN, T., SHIBA, A., ZUBAIR, T., IMRAN, A.E., RIZWAN, A.M., BEENISH, A. and ABBAS, H., 2007. The prevalence of transfusion transmitted infections in healthy blood donors in Rawalpindi district. International Journal of Pathology, vol. 5, pp. 21-25. 